\title{
In Defiance of Meaning: A Study of D. H. Lawrence's Apocalyptic Vision
}

\author{
Roumaissa Moussaoui (Corresponding author) \\ University of Skikda, Algeria, Université 20 Août 1955 ,BP 26, Route d'El Hadaiek-Skikda 21000, Algeria \\ E-mail: roumaissamoussaoui@yahoo.fr \\ Penelope, Sacks- Galey \\ University of Valenciennes, France,FLLASH, Le Mont Houy, 59313 Valenciennes cedex 09, France \\ Email: penelope.galey@sfr.fr
}

Doi:10.7575/aiac.alls.v.8n.1p.152

URL: http://dx.doi.org/10.7575/aiac.alls.v.8n.1p.152
Received: 24/10/2016

Accepted: 17/01/2017

\begin{abstract}
D. H. Lawrence was one of the most controversial writers of the twentieth century who dared to criticize established convention through both his fictional and non fictional works. To this end, he moved away from literary conventions and used language in a new way, took well- known symbols and transformed them into vectors of his own individual and unique thought. Through an examination of his work, Apocalypse, my aim, in this article, is to show how Lawrence negates orthodox religious thinking, by showing not only how religious scribes mutilated and destroyed an original pagan text, but also, how a morphological shift in language helped fuel false ideals. Taking Stoicism as his starting point, I will try to prove that the doctrine of Zeno of Citium, concerning man's affinity with the universe, forms the kernel of truth for his own personal philosophy. This article is divided into three sections. The first section will show how Lawrence shared many of the beliefs of Zeno of Citium, the founder of the philosophy of Stoicism. The second section aims to show how Lawrence defies meaning through an examination of the Book of Revelation. The third section explores apocalyptic symbols revealing Lawrence's unique interpretation of them.
\end{abstract}

Keywords: Apocalypse, symbols, Stoicism, The Book of Revelation, kernel of truth, morphological shift

\section{Introduction}

Throughout his short but meaningful life, D. H. Lawrence was vociferous in his condemnation of modern society and its degradation of the living experience. Centuries of so-called civilization had buried society beneath layers of rigid convention and sterile ideals. In fact, Lawrence saw scientific and technological progress, of which man is so proud, as one of the most important reasons for man's decline. In addition, he believed that philosophy and religion were guilty of the same crime and he set out, ironically, to create a philosophy that would strip away the layers of false beliefs and restore man to his primal state.

To illustrate these ideas, this article is dedicated to an examination of Zeno of Citium's doctrine, that every man's happiness depends upon a healthy relationship with the cosmos. This, later, became the philosophy of Stoicism. I will show that, starting from this kernel of truth, layers of doctrine, and later, dogma, were appended to this idea to form a philosophy or a way of life that, in its very essence, negated it. I aim to show how Lawrence, through his literary genius, managed to create his own philosophy by stripping away the layers of an old-established one-that of Stoicism- and by adapting it to the concepts of contemporary life. Since it is generally upheld that one of the precepts of Stoicism is the repression of emotions, such a stance, in connection with D.H. Lawrence, may seem widely off the mark. However, through an appreciation of Lawrence's work Apocalypse, as a critical examination of The Book of Revelation by John of Patmos, I will try to show how Lawrence defied conventional meaning by stripping away layers of false belief to reveal a vital message which has remained unchanged throughout the ages.

It is generally acknowledged that Lawrence was a deeply religious man and was well-versed in biblical texts. Studies on this subject are numerous and most critics agree that he used Biblical imagery and language to illustrate his apocalyptic vision. In his work, D. H. Lawrence and the Bible, T.R. Wright placed Lawrence firmly among the writers who considered the Bible as the foundation of western literature "The Bible can be said to be a major component in the genesis of his fiction, a stimulus to his imagination, what Bloom calls a precursor-text or poetic father which his own writing attempts to emulate" (D. H. Lawrence and the Bible, 3). He goes on to use Bloom's theories of intertextuality to show how Lawrence's work can be seen as a "supplement to the Bible, both adding to and attempting to supplant the original". Similarly, Shirley Bricout, in her essay L'itinéraire d'un prophète en fuite, reveals how the Bible impacts Lawrence's style and language and, despite his rejection of conventional Christianity, became an essential source for his political and philosophical thought. Both writers recognize that Lawrence pinned his hopes for a renewal of civilization on the reinterpretation of the most influential biblical texts. In fact, Wright suggests that Lawrence personifies himself with Adam as he and Frieda re- enact the Fall of man, "expelled from conventional respectable society" and forced to 
wander around the world in search of paradise, a theme which runs continuously throughout Lawrence's fictional works. Micheal Bell, also recognizes the impact of biblical ideas on Lawrence's language. In his book, Language and Being, he shows how Lawrence rejects conventional orthodox religion in favour of a primitive, deeper belief in the cosmos. In his chapter entitled The Metaphysics of The Rainbow, he shows how Lawrence uses his language to portray how religious feeling is absorbed by the Brangwens into the everyday world. He writes:" They have a powerful sense of what we might call the "divine" but for them this is not separable from the natural" (DH Lawrence: language and being, 83). This article hinges on this precept.

By using Bell's idea as a starting point, I will try to show how man's relationship with the cosmos imbued Lawrence's vision. For him, everything began with the cosmos_science, religion and, by inference, philosophy. In Fantasia of the Unconscious, he differentiates between "subjective science" based on the "data of living experience" and "objective science of modern knowledge" (Fantasia of the Unconscious, 54). He endlessly expounds how conventional religion has its roots in a universal truth, inspired by man's relationship with "the consummate being". From such a stance, then, it is easy to see how, for Lawrence, all philosophical thought could be traced back to a fundamental truth grounded in the cosmos.

Lawrence's works, both fictional and non-fictional, laud "the great pagan world which preceded our own era" (Fantasia of the Unconscious, 54). Like so many of his contemporaries, he railed against the analytical tyranny of the modern world, in particular, the fixed interpretation of much of the literature that stifled the creative mind. He believed that artists of all kinds (writers, artists and sculptures) could use their works as tools for social change. He aimed at being a pioneer and, at the expense of his literary reputation, he tried to lead man away from the suffocating dogma of convention and persuade him to embrace life through innovation and creativity. To do this, he hit hard at the core of the establishment criticizing the orthodox interpretation of biblical texts; thus, undermining conventional authority which, for him, only served to control and restrict the liberty of man. In this article, I am going to illustrate how he re-interprets one of the most important texts of the New Testament, the Book of Revelation, showing how Jewish and Christian scribes mutilated and destroyed the original pagan document to fit their conventional religious doctrine.

"What we care about is the release of the imagination" he says in (Apocalypse, 47). To do this, he tries to illustrate the importance of fluidity of meaning and criticises the modern mind for thinking that "every book is the same". He states that "The real joy of a book lies in reading it over and over again, and always finding it different, coming upon another meaning, another level of meaning"(Apocalypse, 60). To him, it is a question of interpretation and he created a totally new and dynamic form of expression in keeping with his apocalyptic philosophy. He explored language in a new way, took well-known symbols and transformed them into vectors of his own individual and unique thought. In this article, I will isolate these specific apocalyptic symbols to show not only their importance, but also how they are intrinsic parts (functional elements) of his moral philosophy. In doing so, I will prove how his work Apocalypse can be viewed as both a point of departure and a culmination of Lawrence's creative endeavour.

This article is divided into three sections. The first will show how Lawrence shared many of the beliefs of Zeno of Citium, the founder of the philosophy of Stoicism. The second aims to show how Lawrence defies meaning through an examination of the Book of Revelation, and the third explores apocalyptic symbols, revealing Lawrence's unique interpretation of them. In this study, I have used an analytical approach to compare and contrast the teachings of Zeno of Citium with the philosophy of Lawrence. I have explored language in order to indentify the morphological shift responsible for the creation of false beliefs. Through an analysis of the main symbols of the Book of Revelation, I have consolidated my aim to show how Lawrence's innovative vision undermined conventional interpretation and offered an apocalyptic message of renewal and hope which, paradoxically, has always existed.

\section{Lawrence and Stoicism}

This section is dedicated to an examination of the doctrine of Zeno of Citium which later, became the philosophy of Stoicism, showing how it compares with Lawrence's beliefs. Founded in Athens in 301 BC, the term "Stoicism " was originally taken from Stoa Poilike (the painted arch), the place where Zeno taught his philosophy, and it bore no real relation to the conventional meaning of the word that is, "indifference to the feelings of both pleasure and pain" (Matakas) which still prevails today. One of the main precepts of Zeno's philosophy included the belief that man's happiness depended upon his ability to live a life of virtue. By Virtue, he meant the will to live according to the laws of nature. This idea exactly matches Lawrence's thinking who would have undoubtedly argued that if Zeno had found it necessary to reassert such a belief, then, the human race was already, at that time, in a state of decline. Zeno taught that the universe is an active, reasoning substance known as god or nature with his disciple, Chrysippus, defining the universe as "God and the universal outpouring of its soul" (De Natura Deorum, 39). In this way, then, it is easy to see how the morphological shift in the word "virtue", to include both its religious and ethical connotations of modern English, could have occurred.

These pantheistic views were undoubtedly shared by Lawrence who wrote, in 1911, after rejecting his Nonconformist upbringing, "There still remains a God, a vast, shimmering impulse which wavers onwards towards some end" (Apocalypse and Writings of Revelation, 17). The indefinite article "a", in the above quotation, underlines his rejection of THE God of conventional religious belief. It is the god of Zeno and Chrysippus; the "world's guiding principle" that exists "in the common nature of things and the totality that embraces all existence" (Dyck and Cicero). Like the Stoics, he recognized that the essence of god can be found in everything and the basis of his metaphysics was grounded in these ancient beliefs.

The Stoics believed that the substance which makes up the universe could be divided into two classes: the passive and the active. The passive substance, defined by Seneca, as a matter which "lies sluggish, a substance ready for any use, but sure to remain unemployed if no one sets it in the motion" (M.Gummere) is vitalized by the active substance, 
defined as Universal Reason (Logos). According to Zeno, it is this aether, this Logos, which forms the basis of all activity in the universe, having the ability to both destroy and regenerate.

Lawrence recognized this relationship and when he wrote, in his work Apocalypse "I am part of the sun as my eye is part of me. That I am part of the earth my feet know perfectly, and my blood is part of the sea" (Apocalypse, 27), he was not merely speaking metaphorically; he was recognizing "the terrific embrace" of the Chaldean sun and moon. Like the Stoics before him, he understood the wonder of the creative flux which exists between man (passive matter) and these celestial beings (active matter). In his work Apocalypse, he says of the moon "The moon is the great moon still, she gives forth her soft and feline influences, she sways us still, and asks for sympathy back again"(Apocalypse, 53). Similarly, he demands homage for the sun whose invigorating force is the source of life and energy on earth.

The Stoics believed that the relationship between this passive and active matter was confirmed by cosmic determinism. The Logos was seen as a rational force that directed the universe for a single purpose; that is everything happens for the best. From this deterministic viewpoint, the stoics deduced that the consequences of all actions are the result of forces out of our (human beings) control. They argued that man has the ability to reason and, through his reasoning, accept this deterministic outlook. They upheld the values of wisdom and self-control in order to fulfil their duty, which consisted in obedience to the rules of nature. One of the rules of their discipline was "Follow where reason leads" (History of Western Philosophy, 264). Man must strive to be free of the passions and passively react to external events. Stoic virtue consists in the ability of man to amend his will to suit the world in which he lived. To quote the words of Epictetus, a virtuous man must remain "sick and yet happy, in peril and yet happy, dying and yet happy, in exile and happy, in disgrace and happy" (History of Western Philosophy, 264). In the words of the ancient Greeks, the word "passion" meant "anguish" or "suffering": so if a man was to be happy, it was natural that he should free himself from such emotions and transform them into fortitude and calm.

Lawrence, himself, believed in cosmic determinism but his thinking differed from the Stoics in one important point. Although he believed that cosmic elements influenced the fate of man, he FELT that this belief was grounded in intuition rather than in reason. He wrote in Why The Novel Matters that "Right and wrong is an instinct, but an instinct of the whole consciousness in a man, bodily, mental, spiritual at once" (Why the Novel Matters, 171). In this quotation, he underlines his belief that the word "instinct" is more literal a translation of the word "Logos" than the word "Reason", used by the Stoics, with all its connotations of the stultifying control of the mind. He also denigrates the importance these ancient thinkers placed upon the mind, bringing instincts back into the equation and emphasising his holistic approach.

With the advent of Christianity, Stoicism developed into a social tool, translating itself into a fatalistic acceptance of adversity. In $1 \mathrm{BC}$, John of Patmos wrote the Book of Revelation and encouraged Christians to welcome suffering as a sign of God's favour. He taught them to believe that they were the Chosen Ones whose persecution would be rewarded by an eternal place in the kingdom of heaven. They have only to remain calm and accept the faith decreed them by God; hence, the morphological shift on the word stoic was complete. This definition of the word stoic, with all its connotations of repression of the feelings, was of course anathema to Lawrence whose acceptance of cosmic determinism was grounded in the instincts and not in the reason.

The section that follows is dedicated to an examination of the various interpretations of the Book of Revelation showing how they compare to D. H. Lawrence's work Apocalypse. Through this analysis, I aim to show how Lawrence, in his critical genius succeeded, in stripping away the literary "tinkering" of a pagan manuscript which he believed made up the kernel of the book to reveal his own personal and apocalyptic vision.

\section{Lawrence and the Book of Revelation}

The Book of Revelation, the last book of the New Testament, was written around 1 AD by John of Patmos who had been banished by the Roman authorities for his religious beliefs. It has been open to several interpretations but it is generally accepted that he wrote the book, not only as a critic of the society in which he lived, but also as a message of hope to his followers, that their persecution at the hands of the Roman authorities would not be in vain. Good would overthrow evil and martyrdom would be welcomed as a passage of rite for an eternal life in heaven.

These ideas were anathema to D. H. Lawrence. He believed that man should not be placated by the promise of an afterlife. For him, man has only one life and he should live it to the full. Indeed, he culminates his work, Apocalypse, with this thought "Man wants his physical fulfilment first and fore-most, since now, once and once only, he is in the flesh and potent" (Apocalypse, 122). Moreover, he was against the conventional interpretation of the Book of Revelation believing it to be a tool to stifle and control individuality. In a Review of the Book of Revelation by Doctor Oman, which he wrote using the pseudonym L.H. Davidson, he makes a stark criticism of the rigidity of traditional thought and its failure to understand that "an apocalypse has, must have, is intended to have various levels or layers or strata of meaning" (Apocalypse, 41). In a rhetorical question "Why should Doctor Oman oppose the view that, besides the drama of the fall of World Rule and triumph of the word, there is another drama, or rather several other concurrent dramas?" (Apocalypse, 41) he poured out all the scorn he felt for the fixed ideals that had destroyed forever man's liaison with the cosmos.

D. H. Lawrence knew, when he wrote the Review of the Book of Revelation by Dr. John Oman in 1924, that his ideas were really controversial. On March 31"st, 1923, J. Middleton Murry wrote of Lawrence "I felt, and I said, that he was an enemy of civilization. It was perfectly true. He is the conscious and deliberate, yet passionate and potent enemy of modern civilization. If our modern life, our modern civilization, is fundamentally good and true and valuable, then indeed the cry must be raised against D.H. Lawrence." (Dh Lawrence: The Critical Heritage, 184). It is for this reason, then, that he chose to write under a pseudonym, hoping to give his vision more weight and really influence the thought trend of society. 
Writing in Apocalypse that there is "a pagan kernel to the book", (Apocalypse, 98) he believed that the original version of this apocalyptic text belonged to the pre-Christian world and was a symbolic account of how to restore a living connection with the cosmos and find inner harmony. The text, he says, bears witness to "the opening, and conquest of the great psychic centres of the human body" (Apocalypse, 101). For him, it is the account of man's descent into a nihilistic state and his subsequent rebirth into a new life "The old Adam is going to be conquered, die, and be re-born as the new Adam" (Apocalypse, 101). For him, its meaning is symbolical rather than allegorical; its references are astrological rather than biblical and its theme is the "drama of cosmic man" (Apocalypse, 41) rather than "the triumph of the world" (Apocalypse, 41).

D. H. Lawrence believed that generations of scribes had distorted the original account by adding, taking away or transforming important details in order to promote their own conventional views. He states in Apocalypse that the book "was written over perhaps more than once, by Jewish apocalyptists, before the time of Christ: that John of Patmos probably wrote over the whole book once more, to make it Christian: and after that Christian scribes and editors tinkered with it to make it safe" (Apocalypse, 98). Through a series of acerbic and sometimes flippant remarks, he traces the damage made by this "tinkering" and attempts to restore the text to its original meaning. His first criticism of the Book of Revelation concerns the plan which has been "very much broken up" (Apocalypse, 47) by the Jewish need to force "some ethical or tribal meaning in" 97. He goes on, in derogatory fashion, to criticize the mise en scène which, with the addition of Jewish detail, has become, to quote his words, "a complete muddle" (Apocalypse, 97). "we are not surprised" ... "to find the mise en scene of the vision muddled up, Jewish temple furniture shoved in, and twenty-four elders or presbyters who no longer quite know what they are, but are trying to be as Jewish as possible, and so on" (Apocalypse, 97). He admired the "lovely plan" of the ancient apocalyptic text, which was based on the pagan conception of time. Primitive man believed that time moved in cycles and, when one cycle finished, another began, quite like the original one but on a different level.

According to D. H. Lawrence, it is a world based upon the astrological heavens, with the twelve zodiac signs at its centre and time moving in spirals from one level to another. "The "world" is established on twelve: the number twelve is basic for an established cosmos. And the cycles move in sevens." (Apocalypse, 97). This design was too "pagan and immoral" for the Jewish and, later, the Christian scribes who needed to make "things safe" by adopting "our timecontinuum method" and deleting whole passages of "star-lore" (Apocalypse, 98). To this end, then, the Lion of Judah is transformed into a Lamb (the conventional image of Jesus Christ) whereas, in the original pagan text, it would surely have been Aries (The Ram) or Taurus (The Bull). Lawrence points out that these "pagan mysteries of the sacrifice of the god for the sake of a greater resurrection are older than Christianity" (Apocalypse, 99); it is logical then, that this apocalyptic mystery was described in terms of the Zodiac. Leo (The Lion) represents God who received blood sacrifices in the form of either a sheep, (Aries) or a bull (Taurus); they, in their turn, became the sacrificed god whose blood was shed so that mankind could live.

From the very first chapters of the Book of Revelation, John of Patmos establishes his message. The theme of his work is the triumph of the word of God over the evil rampant in the world. To this end, from the very beginning, the symbol of "the book", thought by D. H. Lawrence to have been added by the Jews, is introduced, destroying forever the intended supremacy of instinct and intuition. He says in Apocalypse, "The Almighty has a book in his hand. The book is no doubt a Jewish symbol. They are bookish people: and always great keepers of accounts: reckoning up sins throughout the ages" (Apocalypse, 99). Here, his tone is flippant, even humorous and, although he goes on to say "it is a detail", it is, nevertheless, important and serves to transform the whole meaning of the work. The book becomes a symbol of the mind and the intellect, enforcing John of Patmos's message to his followers that they remain rational and stoic in the face of adversity, with a promise of eternal life in heaven. It is through the influence of the written word that is to say, the book- that conventional religion controls and manipulates the masses.

By pinpointing in detail the additions, suppressions and transformations of the pagan document, D. H. Lawrence succeeded in restoring authenticity to a vision that had been distorted beyond recognition. He has shown how a society can "tinker" with a kernel of truth, twist it into meaninglessness and create a false reality, which becomes a controlling convention. Through a lightly veiled criticism, he infers, in Apocalypse, that what the Christians had done in the Book of Revelation, Freud and his disciples have done to society "We cannot help hating the Christian fear, whose method, from the very beginning, has been to deny everything that didn't fit or better still, suppress it" (Apocalypse, 87). Freud's psychoanalytical theory plays the role of the Christian church and conditions society to repress any emotions that could undermine the status quo. It is the aim of the conscious mind to control the primal urges of the personality or, to quote the words of Lawrence, to "suppress it, destroy it, deny it" (Apocalypse, 87). He concludes with the thought that man are "fools today, for stripping themselves of their emotional and imaginative reactions, and feeling nothing. The price we pay is boredom and deadness" (Apocalypse, 92). He aimed throughout his literary career to revitalize the thought processes of the human mind, re-evaluate the role of intuition and encourage man to search for answers within his inner being.

To this end, Lawrence strived to eradicate the allegorical interpretation of the book and replace it by symbolic interpretation. He understood the power of a symbol to stir the imagination and adapt itself to different interpretations. In A Review of The Book of Revelations by Dr. John Oman, he states "As a matter of fact, old symbols have many meanings, and we only define one meaning in order to leave another undefined" (Apocalypse, 42), recognizing the inexhaustibility of the interpretation of any symbol and seeing it as an appropriate means of expression in apocalyptic writing. He was aware that The Apocalypse means different things to different people and, as such, a symbol should be left with a flexibility of meaning to cover all possibilities. In the same review, Lawrence writes "an Apocalypse has, must have, is intended to have various levels or layers or strata of meaning" (Apocalypse, 41) and he criticizes Dr. Oman's exhaustive explanation as a product of the intellect and not the imagination "Yet we cannot agree that Dr. 
Oman's explanation of the Apocalypse is exhaustive. No explanation of symbols is final. Symbols are not intellectual quantities, they are not to be exhausted by the intellect" (Apocalypse, 41). In his own work entitled Apocalypse, he offers another interpretation, giving the symbols an astrological meaning and relating the drama of cosmic man.

For Lawrence, then, it is a question of interpretation. In the section that follows, I aim to explore the different apocalyptic symbols of the Book of Revelation, comparing their usage with ancient belief and showing how they correlate to D. H. Lawrence's vision. By an analysis of his fictional works, I will show how the author incorporates these apocalyptic symbols within the framework of his creative art to give us a clear picture of his apocalyptic vision. It is not a denial of conventional interpretation. In fact, in the Review of the Book of Revelation by Dr. John Oman, he states "We gladly accept Dr. Oman's interpretation of the two Women and the Beasts" (Apocalypse, 41). It is rather the realisation of the immense freedom in accepting multiple layers of interpretation, giving imagination free reign to create each person's individual vision.

\section{Lawrence and the Symbols of Apocalypse}

His work Apocalypse is his attempt to defy orthodox conventional meaning. Incorporating the whole of his literary vision, he rails against the dogmatic interpretation of the Bible which was "verbally trodden into the consciousness" (Apocalypse, 60), its mystery destroyed at every turn by fixed interpretation. "The Bible is a book that has been temporarily killed for us, or for some of us, by having its meaning arbitrary fixed" (Apocalypse, 60). He goes on to say: "Once a book is fathomed, once it is known, and its meaning is fixed and established, it is dead" (Apocalypse, 60). A book only lives while it has the power to move us, and move us differently, as long as we find it different every time we read it. For Lawrence, a true work of art must appeal to the individual sense of self at the centre of every man.

Although, in his work, he examines the Book of Revelation in the Bible, it is so much more than a simple critique. It is an insight into his own narrative technique. He dismisses the use of allegory with its fixed interpretations as antipathetic to him and unnatural. He goes on to define it as a "narrative description using, as a rule, images to express certain definite qualities. Each image means something, and is a term in the argument and nearly always for a moral or didactic purpose, for under the narrative of an allegory lies a didactic argument, usually moral" (Apocalypse, 48)

Instead, he turns to the use of symbols to give his work "meaning" and make it live. In the "Introduction of the Dragon of the Apocalypse" by Frederick Carter, he says that true symbols defy "superficial allegorical meaning". His argument is, if you give something a meaning, it is automatically limited or fixed. A symbol must live; it must reflect being. He clearly states this in Apocalypse:

"you can't give a great symbol a "meaning", any more than you can give a cat a "meaning". Symbols are organic units of consciousness with a life of their own, and you can never explain them away, because their value is dynamic, emotional, belonging to the sense-consciousness of the body and soul, and not simply mental" (Apocalypse, 48)

I, now, turn to an examination of some of the most important apocalyptic symbols in the Book of Revelation, discussing their conventional interpretation in the light of Lawrence's unique and innovative thought.

\subsection{The horse}

Throughout the ages, the horse has always been considered a symbol of power and a source of life. D. H. Lawrence shared these beliefs, describing the horse in chapter X of his work Apocalypse as "the symbol of surging potency and power of movement, of action, in man" (Apocalypse, 102). As "a dominant symbol" (Apocalypse, 101), he recognizes its importance in the Book of Revelation and goes on to interpret the four horseman in his own personal way. For him, they represent one of two things: the first, according to the four humours of Hippocrates, the second according to the four planetary natures of man as laid down the Chaldean astrologists. In the first way, the four colours of the horses (white, red, black and pale) correspond to the four natures of man (sanguine, choleric, melancholic and phlegmatic). The second meaning highlights the interrelation between man and the universe. The Chaldean astrologists believed that the four primary natures of man (jovial, saturnine, martial and mercurial) correspond to the sun and the planets Mars, Saturn and Mercury.

If these interpretations are correct, then, it is no surprise that John of Patmos, and the Jewish apocalyptists, before him "cut away" the astrological references transforming the horse from a symbol of potency and life into an emblematic representation of future events. This, according to Lawrence, was a deliberate attempt to make the pagan document acceptable to the Orthodox Church:

"The original meaning, which was pagan, is smeared over intentionally with a meaning that can fit this" Church of Christ versus the wicked Gentile Powers" business. But none of that touches the horsemen themselves. And perhaps here better than anywhere else in the book can we see the peculiar way in which the old meanings has been cut away and confused and changed, deliberately, while the bones of the structures have been left." (Apocalypse, 104)

All the interesting and vital cosmic details have been cut away leaving the Apocalypse, to quote the words of D. H. Lawrence in chapter X of his work of the same name, "a string of cosmic calamities, monotonous" (Apocalypse, 105). Through his words "In they ride, short and sharp and it is over. They have been cut down to a minimum" (Apocalypse, 101), he manages to convey his derision for the scribes and editors, who had destroyed, forever, the astrological and zodiacal magic of these symbols. His aim , in his work, is to try to restore the pagan vision to its former glory, "to have back the pagan record of initiation" (Apocalypse, 101) and highlight his own apocalyptic beliefs.

According to orthodox interpretation, the four horsemen of the Apocalypse, described in chapter 6 of the Book of Revelation, are symbolic descriptions of different events which John of Patmos prophesised would take place before the end of time. The first horseman ,riding a white horse, is interpreted, in conventional thinking, as the antichrist who will be given authority and conquer all who oppose him. The antichrist parallels the true Christ who returns at the end of 
Apocalypse, also mounted on a white horse. For Lawrence, however, the white horse represents life, which shines with a dazzling, white light. In Apocalypse, he explains how the blood of life can be seen as white "in our old days, the blood was the life, and visioned as power it was like white light" (Apocalypse, 102). In Revelation, chapter six, verse two, the rider of the white horse "held a bow, and he was given a crown, and he rode out as a conqueror bent on conquest" (Carroll and Prickett). For Lawrence, this is not the antichrist; it is "the royal me" (Apocalypse, 102) and his horse is "the whole mana of a man". He is the "very self" who must ride out and conquer the old self in anticipation of the birth of a new self. Lawrence compares him both to the sun and the moon "And he rides forth, like this sun, with arrow, to conquest, but not with the sword, for the sword implies also judgement, and this is my dynamic or potent self. And his how is the bended bow of the body, like the crescent moon" (Apocalypse, 103). The last rider on the white horse at the end of the Book of Revelation is ,for Lawrence, the true self, triumphant and victorious, leading "his hosts" to life. He negates verse fifteen of chapter nineteen of Revelation "And out of his mouth goeth a sharp sword, that with it he should smite the nations: and he shall rule them with a rod of iron" (Apocalypse, 103) as a Jewish addition, conjuring up the picture of a controlling and vengeful god. This is an anathema to D. H. Lawrence. The sword, he said, implies judgement and would have been absent from the pagan record "Let us go back to the bow and arrows of him to whom judgment is not given" (Apocalypse, 103).

The second horseman, appearing in Revelation, chapter six verse four, was intended by John of Patmos to prophesize a terrible period of warfare, which would inevitably break out before the end of the world, between the supporters of the antichrist -the false religion- and the followers of the true God. For Lawrence, the red horse represents choler "not mere anger, but natural fieryness, what we call passion" (Apocalypse, 102). He goes on to say that, with the appearance of the second rider, "strife and war enter the world" (Apocalypse, 103). It is not the physical world of which he speaks but "the inner world of the self" (Apocalypse, 103). The conflict is the struggle between the conscious and the unconscious mind or, to use the words of Sigmund Freud, the super ego and the id.

John of Patmos uses the third horseman, astride a black horse, to prophesise a period of austerity and famine, the inevitable outcome of the wars with the second horseman. The writer's message is clear. The followers of the true religion will be faced with a period of scarcity and corruption, leaving them weak and poor. In contrast, and underlining the influence of Freud, for Lawrence, the black horse represents the ego, the conscious mind, which must try to find a balance between the superego and the id. In his work, Apocalypse, it is represented as black bile, in an effort to portray modern man's predicament: the ego has chosen the super ego over the id and intuition has been sacrificed to convention. "Bread" he says, symbolises the flesh or physical instincts, which had been "symbolically sacrificed" in favour of false ideals. His imagery is powerful. Bile is a necessary element for digestion in the human body but, when in excess, can result in death. By inference, the ego "carries the balance of measure" (Apocalypse, 103) in the human personality but, when its influence is biased, individuality is automatically sacrificed to conventionality: to Lawrence, this means "death".

The fourth horseman of the Apocalypse, riding a pale horse, is symbolic of death and destruction. The inevitable outcome of strife and war; famine and deprivation, is, for John of Patmos, the physical death of the believers to be followed by a period of purgatory, until they reach their destined place of an eternal life in heaven. The rider on the pale horse, also represents death for Lawrence but it is the death of the physical and dynamic self, "the "little death" of the initiate" which forces man to retreat into "the underworld" of his "being" (Apocalypse, 103) in preparation for his rebirth onto a new and vital plane.

\subsection{The underworld}

A second important symbol of this apocalyptic text is the underworld. In most civilisations, it is believed to be a nether world, deep underground, where souls go after death. In most conventional religions, it is known as Hades or hell, a place of punishment and retribution for evil committed during an earthly life. In the Book of Revelation, however, it is difficult to equate "the souls of them that were slain for the word of God" (Carroll and Prickett) with the inhabitants of hell. The underworld in chapter six of Revelation is really purgatory, an intermediate state; a place of limbo where the souls of the dead undergo purification as they wait for the Day of Judgement. Indeed, John of Patmos sets out this prophecy in verse eleven of chapter six "and it was said unto them, that they should rest yet for a little season, until their fellowservants also and their brethren, that should be killed as they were, should be fulfilled" (Carroll and Prickett). The words "that they should rest yet for a little season" portray the transient nature of their stay in the underworld. They must fulfil the prophecy that awaits "their fellow servants" and "their brethren" and embrace their martyrdom to gain an eternal place in heaven.

Lawrence believed that verses nine, ten and eleven of chapter six of the Book of Revelation were deliberately inserted by John of Patmos in order to fuel his message and give weight to his prophecy. In Apocalypse, he writes "so the Jewish and Christian apocalyptists abolish the mystery of the individual adventure in Hades and substitute a lot of martyred souls crying under altar for vengeance" (Apocalypse, 104). In just three short verses, the scribes of conventional religion change forever the tone of the pagan script. It is up to Lawrence to rekindle "the mystery of the individual adventure into Hades" and restore "the mortal and terrestrial divinity of man" (Apocalypse, 104)

For Lawrence, who believed that the pagan script recorded man's struggle to find his individuality, the underworld represents "the inner world of the self". The imagery is poignant. Although pagan man understood the inner self better than modern man, it was still a mystery for him and considered to be a place of darkness. Even with the advent of psychoanalysis, the unconscious remains an enigma, despite the numerous studies about it. Lawrence himself admits this at the end of his work Psychoanalysis and the Unconscious "So, the few things we have to say about the unconscious end for the moment. There is almost nothing said. Yet it is a beginning" (Apocalypse, 49). Since, for him, the unconscious is synonymous with life, he is expressing, here, its indefinable mystery and illimitable nature. 
In his work Apocalypse, Lawrence equates this descent into the underworld with the descent into a state of nihilism. In order to restore his mortal and terrestrial "divinity", man must strip away the false identity invested on him by convention, reach a state of nothingness and transcend it, to embrace a new identity based on his own creative individuality. In chapter $\mathrm{X}$, he describes the journey through the underworld as the place "where the living "I" must divest itself of soul and spirit, before it can at last emerge naked from the far gate of hell into the new day" (Apocalypse, 104). The word "naked" is a key word here. The living " $I$ " must be totally free of constraints and must return to its primal state in order to be born again, and invest a new identity based on its own individual nature. For Lawrence, man is reborn in the flesh. It is only a figurative death -the old self dies to be replaced by a new and vital being- "The four bodily natures are put off on earth. The two divine natures can only be divested in Hades. And the last is a stark flame which, on the new day, is clothed anew and successively by the spiritual body, the soul-body, and then the "garment" of flesh, with its fourfold terrestrial natures." (Apocalypse, 104). This, says Lawrence, is the antithesis of the Jewish and Christian tradition where man can only achieve divinity "when he is dead and gone to glory" (Apocalypse, 104).

For Lawrence, then, the underworld is, indeed, the realm of the subconscious, itself buried beneath layers of convention and false ideals. This idea is clearly illustrated in his poem Snake written in 1921. This golden reptile, which came from "the burning bowels of the earth", symbolizes the instincts buried deep within the unconscious mind but ready to surge unpredictably without warning. Lawrence wrote this poem while living in Sicily, close to Mount Etna and the setting is highly symbolic. Just as the earth relieves pressure by erupting volcanic excrement, the mind, unable to contain its emotions and feelings, intermittently explodes. The poem recounts the author's struggle to reconcile conflicting emotions in his encounter with the snake:

"The voice of my education said to me

He must be killed,

For in Sicily the black, black snakes are innocent, the gold are venomous.

And voices in me said, If you were a man

You would take a stick and break him now, and finish him off.

But must I confess how I liked him,

How glad I was he had come like a guest in quiet, to drink at my water-trough" (D. H. Lawrence Snake)

The imagery is clear. Man is torn between the dictates of convention, which have consistently taught him to quell his emotions, and his instinctive attraction to them. In other words, the ego is constantly under pressure from the demands of the id, on the one hand, and the super ego, on the other. The poet describes the snake "Like a king in exile, uncrowned in the underworld" and "one of the lords of life". For him, feelings and emotions are paramount but their position has been usurped by the sterile authority of the mind. In an act of defiance, he picks up "a clumsy log" and throws it at the water- trough just as the snake slithers back into the black hole. It is an act of frustration with both himself, for not having the courage to join the snake at the trough, and the snake, for his "undignified haste". The poet rails at the voice of convention which has stopped him, once more, from fulfilling himself. All the scorn of his predicament can be felt through his words "I despised myself and the voices of my accursed human education" (D. H. Lawrence Snake). The change in society is well overdue the snake is "Now due to be crowned again" (D. H. Lawrence Snake) and man must strive to overcome the iron grip of convention and allow the demands of his primal self, which intermittently erupt to the surface, to lead him into a new way of life.

\subsection{The dragon}

In the Book of Revelation, the serpent is associated with the dragon and represents the forces of evil that threaten the stability of the world. Indeed, in most biblical texts, it is synonymous with Satan (the devil). In chapter twenty of the Book of Revelation, verse two, religious scribes juxtapose all four in the same verse: "And he laid hold on the dragon, that old serpent, which is the Devil, and Satan, and bound him a thousand years" (Carroll and Prickett) emphasizing their negative connotations and changing their image forever. It has become a malevolent force which "deceiveth the whole world" (Apocalypse, 119) and must be cast out in order to restore goodness to mankind.

In his work Apocalypse, D. H. Lawrence deplores these "horrible Salvationists" (Apocalypse, 122) efforts to degrade the two symbols. He writes in chapter XVI "The Dragon is one of the oldest symbols of the human consciousness" (Apocalypse, 123) and celebrates it as "a wonder" to be revered and upheld as a symbol of life. He, too, associates it with the serpent and uses his chapter not only to restore the symbol to its former glory but to repudiate his "accursed human education". In the second paragraph of the chapter, he writes "First and foremost, the dragon is the symbol of the fluid, rapid, startling movement of life within us. That startled life which runs through us like a serpent, this is the dragon" (Apocalypse, 123). By starting with the time sequence "first and foremost", he successfully obliterates all false interpretations of the symbol. He reverses two thousand years of religious dominance by shocking his readers with the truth: John of Patmos and a multitude of scribes before him have denied their followers of life. Their message has always been that, if man dares to listen to his inner being, to follow his instincts -in other words, to live- then, he will be denied his ultimate reward: an afterlife in heaven.

To dispel this culture of anti-life and to illustrate his holistic vision, Lawrence takes us on a mystical journey back to primitive man. "Primitive man" he says in Apocalypse "was in a certain sense afraid of his own nature" (Apocalypse, 123). He had the capacity to understand that a positive emotion or a feeling could unexpectedly become destructive. Taking his cue from Chinese mythology, D. H. Lawrence uses his fictional works to illustrate how the green dragon of our inner being -described by him as the "life-bringer, life-giver, life-maker, vivifier" (Apocalypse, 124) - can become not only the red dragon of destruction but ultimately rebirth. 
There are no physical dragons in the fictional works of D. H. Lawrence but this mystical creature is ,nonetheless, apparent. In the beginning of chapter XVI of Apocalypse, he points us in the direction of his thought and shows us how to understand his literary vision. The dragon is a figurative image for the power and potency within us. It is the element which makes us individual; "which can lie quite dormant, sleeping", but has the ability "to leap out unexpectedly". He describes it as "the sudden accesses of violent desire, wild sexual desire, or violent hunger, or a great desire of any sort, even for sleep". It is an element over which man has no control and can ultimately destroy him "The hunger which made Esau sell his birthright would have been called his dragon: later, the Greeks would even have called it a "god" in him" (Apocalypse, 123). The word "god" is significant here: it is a high authority to which he must obey "it is something beyond him, yet within him". This returns us, once more, to the idea of predestination. Although it sometimes seems that fate "has the better of him", the destruction reaped by the red dragon, is most often constructive; it is the catalyst necessary to thrust man into a new cycle of being and to revitalize his life.

In The Rainbow, Tom's attraction to Lydia's foreignness, and his thirst to break with convention by marrying her, can be seen as his green dragon_a way to fulfil his inner being and remain true to himself. As the relationship develops, Lawrence shows how this same attraction can transform itself into an inimical obsession which threatens to undermine their relationship. Indeed, in Apocalypse, he states "The green dragon becomes with time the red dragon. What was our joy and our salvation becomes with time, at the end of the time-era, our bane and our damnation." (Apocalypse, 125) Through a series of short, sharp sentences and rhetorical questions, he shows how Tom's uncertainty becomes jealousy of Lydia's past, leading to the need to possess her and restrict her freedom. These negative emotions result in rupture which is, in itself, a catalyst to a creative union. Indeed, in Psychoanalysis and the Unconscious, Lawrence states categorically that "Life cannot progress without these ruptures, severances, cataclysms". We deduce from this that the red dragon of the inner being is as important as the green dragon.

Society can learn an important lesson from D. H. Lawrence's vision. Change, although frightening, is necessary if society is to remain creative and alive. In Apocalypse, he sets out "a piece of very old wisdom" which "will always be true" (Apocalypse, 125). In the beginning, an idea, is synonymous with the green dragon and revitalizes society. Through the passage of time, however, it inevitably becomes a convention and, by so doing, deteriorates into potent sterility. It transforms into the red dragon, destructive and deadly. He writes "The god of the beginning of an era is the evil principal at the end of that era. For time still moves in cycles. What was the green dragon, the good potency, at the beginning of the cycle has by the end gradually changed into the red dragon, the evil potency" (Apocalypse, 125). The Christian era has reached its end, according to Lawrence "The good potency of the beginning of the Christian era is now the evil potency of the end" (Apocalypse, 125) and must be overthrown and replaced by the dawn of a new day "Now we have to conquer the Logos, that the new dragon gleaming green may lean down from among the stars and vivify us and make us great" (Apocalypse, 126). The word "conquer" written in italics in the text, underlines Lawrence's belief that man should take control, once more, of his life, defeat the dictates of sterile convention and revitalize himself through his union with the cosmos.

\subsection{The woman}

Another important symbol in the Book of Revelation is the woman. In fact, there are two women in this biblical text: one ,representing the Virgin Mary, in chapter twelve, and the Whore of Babylon, in chapter seventeen. They have been subject to many interpretations but Orthodox Christian mythology equates the woman "clothed with the sun, with the moon under her feet, and on her head a garland of twelve stars" (Carroll and Prickett) (verse 1) with the true church . This interpretation can be seen as the most appropriate since, throughout the Bible, the church is described as a woman and her followers as virgins. By contrast, the woman "arrayed in purple and scarlet colour, and decked with gold and precious stones and pearls" (Carroll and Prickett) (chap 17.3) represents the false church whose role is to deceive the followers and deter them from their path of righteousness. John of Patmos probably intended it to represent the Catholic Church in Rome, which had exiled him for his nonconformist beliefs.

Recognizing that the two women were taken from pagan scripts and inserted into the biblical text, D. H. Lawrence understood that they had apocalyptic potential. He opens chapter XVI of his work, Apocalypse, with the words "The woman is one of the wonders" (Apocalypse, 123). Tracing her history from the leaders in a matriarchal society to the "strange "spiritual" creature" of women today, he uses the biblical text to show that the woman has not really changed her status in society. Despite all her efforts to attain fulfilment, she has been thwarted both by the chauvinistic attitude of her male counterparts and by her own inner nature. She is chained, says Lawrence, to the dragon of convention and "has no power of escape till man frees her" (Apocalypse, 123). This quote is significant on two levels. The man will only free her if he casts off his chauvinistic attitude and recognizes her as his equal but he will only do this, according to Lawrence, if she ,paradoxically, reveals her true nature. For centuries, women were chained to convention making them subservient to man but, with budding emancipation, she became imprisoned by the need to be "significant" and "make something worth while" of her life. This is only an illusion of being free. In fact, she has merely exchanged one false identity for another. She has been too preoccupied in being something; she has forgotten to simply BE.

Through his criticism of the modern woman, Lawrence shows how she has lost their vitality; how the green dragon of inspiration has become the red dragon of "a fixed and evil form" (Apocalypse, 123). By using the myth of Andromeda as illustration, he urges women to cast off their false identity and become "woman" once more, worthy of a union of equality with man. In Lawrence's vision, a creative union is the fruit of equally-matched opposites; the union of masculinity with femininity, of strong men and strong women. Both men and women are responsible for "the horrid grip of the evil-smelling old Logos!" (Apocalypse, 127). and, according to Lawrence, it is time for change. 
"Oh lovely green dragon of the new day, the undawned day, come, come in touch, and release us from the horrid grip of the evil-smelling old Logos! Come in silence, and say nothing. Come in touch, in soft new touch like a spring-time breeze, and shed these horrible police-woman sheaths from off our women, let the buds of life come nakedly!'” (Apocalypse, 127).

The word "nakedly", is poignant here. In its figurative sense, Lawrence meant that both men and women should free themselves from the grip of convention and strip away the layers of false identity to find the kernel of truth. Both Tom and Lydia, in The Rainbow, were able to put aside their differences and recognize that the details of nationality and class were insignificant and powerless to detract from the potency of their union. Likewise, in The Virgin and the Gypsy, the physical nakedness in the union between Yvette and the gypsy has a similar symbolic meaning. By stripping away their clothes, the two young people are able to consummate their union on an equal footing. Barriers of class and status have been symbolically washed away by the ravaging waters of the flood and the physical union between the rector's daughter and the wayward gypsy paves the way for a new era where such considerations will no longer have their place.

\subsection{The twins}

Throughout most civilisations, and their mythology and folklore, twinship is a recurrent theme. Associated with both gods and goddess, these mysterious beings were subject to many interpretations, incorporating the opposing forces of good and evil or, in some cultures fortune and misfortune. In the same culture, they can sometimes represent two different things; contrasting moral forces in a polaristic cosmos, on the one hand, or opposing moral forces in a dualistic universe, on the other. One version of the Egyptian creation myth, for example, portrays the earth god Geb, and the sky goddess Nut as lovers, locked in a tight embrace. When separated with air by the great god Ra. Nut was left to arch across the heavens above Geb. In this legend Nut and Geb complement each other and form a whole. In a second Egyptian myth, the twin gods, Osiris and Set, sons of Nut and Geb, are seen to be rivals. Determined to be born first, Set tore his way out of his mother's womb before being fully formed. His subsequent jealousy and envy of his brother, forced him to eventually kill him.

In the Book of Revelation, the mysterious twins of old mythology have been replaced by the two witnesses, identified by orthodox commentators as Moses and Elija who accompanied Jesus in the transfiguration on the mount. D. H. Lawrence in his work, Apocalypse, berates both the Jewish and Christians scribes who have according to him "balked this bit of Revelation" (Apocalypse, 115). He goes on to unravel the muddle they have created and restore "the little ones, who had such power over the nature of man" (Apocalypse, 115) to their rightful place at the centre of the pagan text. When the text is stripped "down pretty well to a pagan bed-rock" (Apocalypse, 119), it is clear, for Lawrence, that they bear witness to "the two alternate form of elemental consciousness, our day-consciousness and our nightconsciousness, that which were are in the depths of night, and that other, very different being which we are in bright day" (Apocalypse, 117). In chapter XIV, he declares them as rivals "who hold things asunder" "dividers, separators, for good as well as for ill: balancers" (Apocalypse, 116). In Freudian terms, they can be seen to fulfil the role of the superego, controlling the ego and repressing the id. He states "And all the time, they put a limit on man. They say to him, in every earthly or physical activity: Thus far and further_They limit every action, every earth action, to its own scope, and counterbalance it with an opposite action" ... "They make life possible; but they make life limited" (Apocalypse, 117). "The beast from the abyss" represents the suppressed id which surges up in a wave of destruction to kill "these two guardians", regarded as a sort of policemen in "Sodom" and "Egypt". There ensues a period of nihilism until man is able to re-assert his individuality and embrace his true identity.

In the fictional works of D. H. Lawrence, there are no real twins, in the physical sense of the term, but the author uses the dual symbolism inherent in Egyptian mythology to illustrate his concept of polarity. As we have already discussed, the twins, for the Egyptians, represented opposing forces, incorporating both principles of duality and polarity. The twins, as rivals, illustrate the principle of duality where the positive and negative elements conflict with each other and cause division. The twins, as lovers, portrayed in the first creation myth, convey the principle of polarity where the opposite forces attract and complement each other. Polarity creates balance, while duality creates chaos. Through his work Apocalypse, Lawrence makes it clear that the twins, as rivals are destructive to mankind. Duality is the product of human judgement and it is responsible for so much suffering in the world. The twins, the rivals, the instigators of judgement must die to allow human nature to move onto a new and creative plane. In Apocalypse he states "Thus the earth, and the body, cannot die its death till these two sacred twins, the rivals, have been killed" (Apocalypse, 118). For Lawrence, duality must turn into polarity if human nature has any chance of survival.

Throughout his works, this controversial writer aimed to create LIFE. In his holistic approach, he was aware that human nature was composed of contrasting elements (positive and negative emotions, masculine and feminine instincts, rational and irrational tendencies) which should not be separated. In an article entitled The Reality of Peace, he writes "We are tigers, we are lambs". The decisiveness of these two short sharp sentences is contradicted by the subsequent phrase "Yet are we also neither tigers nor lambs, nor immune sluggish sheep". Lawrence successfully manages to convey the indefinable nature of life. He goes on to assert that if man is to live, he must recognize all opposing forces within him and try to reach a creative balance: "Yes, we are tigers, we are lambs, both in our various hour. We are both these and more. Because we are both these, because we are lambs, frail and exposed, because we are lions, furious and devouring, because we are both, and have the courage to be both, in our separate hour, therefore we transcend both, we pass into a beyond, we are roses of perfect consummation. The Reality of Peace" (Phoenix: The Posthumous Papers of Dh Lawrence, 69). Only when man accepts the twin forces of his own nature, will he be ready to embrace the polarities of a full relationship within a new society. 
As one of the greatest writers of all time, it is credit to his literary genius that Lawrence was able to use his language to illustrate his philosophy and create a true apocalyptic vision. He wanted to make us live, through our senses, through our instincts, and through our feelings. He wanted his message to reverberate, through our mind and body, through our blood and intuition, through our consciousness and unconsciousness, through our spirit and intellect. In fact, what he wanted to portray was Life.

He was disillusioned with the didactic analytical approach that characterized the twentieth century and tried in his works to defy meaning. As he says in Etrucian Places, if he could, as a creative writer, make his work live then there would be "no need to force the mind and soul in any direction" (Lawrence). The reader through his receptivity would be able to decide for himself.

In Apocalypse, he urges the modern reader to divorce himself from the ideal of "quantity" and look once more for "quality" 60. He says that to read one book several times and "get a more profound experience every time" is far better that to read several books only once. "The real joy of a book lies in reading it over and over again, and always finding it different, coming upon another meaning, another level of meaning" (Apocalypse, 60). My studies on D.H. Lawrence have convinced me this controversial writer succeeded in transcending meaning to reach a level defying interpretation and allowing the imagination free reign.

\section{References}

Bell, Michael. DH Lawrence: language and being. Cambridge University Press, 1992.

Carroll, Robert, and Stephen Prickett. The Bible: Authorised King James Version with Apocrypha. Oxford University Press, 1997. Print.

Shirley BRICOUT. L'itinéraire d'un prophète en fuite ou Le texte biblique et la réflexion politique dans Aaron's Rod, Kangaroo et The Plumed Serpent de D.H. Lawrence. Montpellier : PULM, Université Montpellier III, 328 pages, 2008. ISBN 978-2-84269-852-2.

Draper, Ronald P. D. H. Lawrence: The Critical Heritage. Psychology Press, 1997. Print.

Dyck, Andrew R., and Marcus Tullius Cicero. Cicero: De Natura Deorum, Liber I. Cambridge [u.a.]: Cambridge Univ. Press, 2003. Print.

Lawrence, D. H. Apocalypse. Penguin ed1995. Print.

Lawrence, D. H., and Mara Kalnins. Apocalypse and the Writings on Revelation. Cambridge: Cambridge University Press, 2002. Print.

Lawrence, D. H. Etruscan Places. Read Books Ltd, 2013. Print.

Lawrence, D. H. Fantasia of the Unconscious. T. Seltzer, 1922.

Lawrence, D. H. Phoenix: The Posthumous Papers of Dh Lawrence. Heinemann, 1936. Print.

Lawrence, D. H. Snake. 1923. 2016. <http://homepages.wmich.edu/ cooneys/poems/dhl.snake.html>.

Lawrence, D. H. Why the Novel Matters. Study of Thomas Hardy and Other Essays (1936): 193-8. Print.

M.Gummere, Richard. Seneca, Epistle, Volume Ii. 1920. Print.

Matakas, Chris. Modern Stoicism. 2016. <http://buildthefire.com/modern-stoicism/>.

Russell, Bertrand. History of Western Philosophy: Collectors. Edition. Routledge, 2013. Print.

Wright, Terence R. DH Lawrence and the Bible. Cambridge University Press, 2000. 